\title{
小児脛骨遠位端 Triplane 骨折の治療経験
}

長崎県立島原温泉病院整形外科
小
常 岡 武 久・大久保 嵩 志
太 田 雄 三

Triplane Fractures of Distal Tibial Epiphysis in Children

\author{
Hironobu Koseki, Yukimasa Nishimura, Takehisa Tsuneoka, \\ Takashi Ohkubo and Yuzo Ohta \\ Department of Orthopaedic Surgery, Shimabara Onsen Hospital
}

The purpose of this study is to study the mechanism of injury and to introduce a reduction method. 13 cases of triplane fracture in the distal tibial epiphysis treated in our hospital were reviewed clinically. There were 8 males and 5 females with an average age of 13.1 years old (range; 9 to 14 years). The average follow up period was 2 years 2 months (range; 6 months to 7.5 years). 8 cases were forced planter flexion-external rotation of the ankle at injury, only external rotation was seen in a case except for other unexplained cases. All cases were challenged closed reduction under spinal anesthesia, of which 7 cases required open reduction and internal fixation.

They recorded 98.2 points with the JOA score at follow-up. The length gap of the lower extremities was not explained clearly. The external rotation force of the ankle, in addition to the planter flexion force, is the most suspectable cause of the occurrence of triplane fracture. Manual reduction with $\mathrm{K}$-wire inserted displaced fragments of the tibia is useful for cases which reject closed reduction.

Key words : Triplane fracture（Triplane 骨折), Distal end of tibia（脛骨遠位端), Children（小児）

はじめに

小児の外傷性骨端線損傷において脛骨遠位端は好発 部位の 1 つであり ${ }^{2)}$, 特に Triplane 骨折は骨端線が 閉じる比較的限定した期間に発生する．本症は関節面 に至る特徴的な骨折型を呈するため治療に際しては正 確な解剖学的整復が必要である ${ }^{3) 8)}$. 今回我々は当科 で治療した本骨折例について追跡調查を行い，特にそ の受傷肢位と整復法について検討したので報告する.

\section{対象および方法}

対象は過去 15 年間に当科で治療した Triplane 骨
折 13 例, 13 足であり, 男性 8 例, 女性 5 例, 患肢は 右 8 例で左 5 例であった。受傷時年龄は $9 \sim 14$ 歳 (平均 13 歳 1 ケ月) で, 男性が $9 \sim 14$ 歳（平均 13 歳 6 ヶ月）女性が $11 \sim 13$ 歳（平均 12 歳 3 ヶ月）であり, 追跡調查期間は 6 ヶ月〜 7 年 5 ヶ月（平均 2 年 2 ヶ であった（表 1 )。

受傷原因はスポーツ外傷が最も多く 10 例であり, 以下転落 2 例, 交通事故 1 例であった，骨折型は 2 Part が 9 例， 3 part が 3 例， 4 part が 1 例であり， 腓骨骨折を伴っていたのは 7 例であった.

追跡調查時 X線学的評価と JOA score を用いた臨 休的評価を行い, 脚長差, 回旋変形治瘉なども併せて 
調査した.

結果

受傷機転は不明の 4 例を除いた 9 例中, 底屈一外旋 強制を受けたのが 8 例，外旋強制は 1 例であった.

外来受診時, 全例において腰椎麻酔下にまず徒手整 復を試み， 13 例中 6 例はギプス固定としたが，整復 位を獲得できなかった 7 例は観血的に整復し，内固定 した．整復は全例で内旋力を末梢骨片に加えることで

表 1 対象症例の内訳

\begin{tabular}{|c|c|c|c|c|c|}
\hline & 年尌紫) & 性別 & 受傷原因 & 患側 & 特骨骨折 \\
\hline 1 & 11 & 女 & ローラーブレードで転倒 & 右 & なし \\
\hline 2 & 14 & 男 & サッカーで転倒 & 左 & なし \\
\hline 3 & 12 & 女 & 走行中転倒 & 左 & なし \\
\hline 4 & 13 & 男 & 交通事故 & 右 & あり \\
\hline 5 & 14 & 男 & 高所より転落 & 右 & あり \\
\hline 6 & 13 & 女 & 転落 & 左 & なし \\
\hline 7 & 13 & 男 & サッカーで転倒 & 右 & あり \\
\hline 8 & 11 & 女 & 転落 & 左 & あり \\
\hline 9 & 14 & 男 & サッカーで転倒 & 右 & あり \\
\hline 10 & 13 & 女 & ローラースケートで転倒 & 右 & なし \\
\hline 11 & 14 & 男 & サッカーで転倒 & 右 & なし \\
\hline 12 & 9 & 男 & サッカーで転倒 & 右 & あり \\
\hline 13 & 14 & 男 & バスケットで転倒 & 左 & あり \\
\hline
\end{tabular}

得られており, 足関節の背屈や前方への引き出しだけ では得られなかった（表 2 ).

JOA score は $90 \sim 100$ 点（平均 98.2 点）であった。 走行時（後）の疼痛を 2 例に, 軽度の背屈制限を 3 例 に，僅かな外旋変形を 1 例に認めたが，全例で脚長差 は認めなかった．X線学的には $4 \mathrm{~mm}$ の転位を残し た例で天蓋角 ${ }^{6)}$ の減少を認めた。

次に代表的症例を供覧する。

症例 $1: 13$ 歳, 女性

ストレッチ体操をしていて着地した際，左足関節外 旋強制を強いられ受傷した。初診時単純X線像上, 前 後像で Salter-Harris III 型, 側面像で II 型を呈し, Triplene 骨折と診断した。腰椎麻酔下に徒手整復を 試みたが，整復困難であったため前外方アプローチで 観血的整復術を施行した．骨折部を露出すると脛骨外 側の骨端部を伴う後果骨片が後方へ落ち込んで陥頓し ていた．動摇性がなかったため離開骨端線部にエレバ トリウムを挿入し，内旋一前方引き出し強制を行うと 整復された，整復後の転位は $1 \mathrm{~mm}$ 未満であり，固 定性も良好であったが念のため脛骨外側より $\mathrm{K}$-wire を刺入して内固定を行った． 4 週間のギプス固定後, 部分荷重歩行訓練を開始した。受傷後 5 年 1 ヶ月の現 在, JOA score 100 点でX線学的にも健側と形態的 差はなく, ADL 上何ら支障なく生活している (図 1).

表 2 対象症例の受傷肢位, 治療法, JOA score

\begin{tabular}{|c|c|c|c|c|}
\hline & 受傷肢位 & 整復肢位 & $\mathrm{JOA}$ (点) & 手術方法 \\
\hline 1 & 底屈一外旋 & 内旋 & 98 & $\mathrm{~K}$-wire を使って整復, $\mathrm{K}$-wire 2 本経皮的内固定 \\
\hline 2 & 底屈－外旋 & 前方引き出し+内反内旋 & 95 & 踵骨鋼線牽引，観血的整復， $\mathrm{K}$-wire 2 本経皮的内固定 \\
\hline 3 & 底屈一外旋 & 背屈+内旋 & 100 & 徒手整復, ギプス固定 \\
\hline 4 & 不明 & 内旋 & 93 & 徒手整復, ギプス固定 \\
\hline 5 & 外旋 & 前方引き出し＋内旋 & 90 & 踵骨鋼線牽引, 観血的整復, ギプス固定 \\
\hline 6 & 不明 & 前方引き出し+内旋 & 100 & エレバで観血的整復, $\mathrm{K}$-wire 内固定 \\
\hline 7 & 不明 & 背屈＋内旋 & 100 & 観血的徒手整復, $\mathrm{K}$-wire 1 本, screw 1 本内固定 \\
\hline 8 & 底屈－外旋 & 背屈＋内旋 & 100 & 観血的徒手整復, screw 2 本内固定 \\
\hline 9 & 底屈－外旋 & 内旋 & 100 & 徒手整復, ギプス固定 \\
\hline 10 & 底屈一外旋 & 内旋 & 100 & 徒手整復, ギプス固定 \\
\hline 11 & 底屈－外旋 & 前方引き出し+内旋 & 100 & 徒手整復, ギプス固定 \\
\hline 12 & 底屈－外旋 & 毫引－前方引き出し +内旋 & 100 & 徒手整復, ギプス固定 \\
\hline 13 & 不明 & 背屈＋内旋 & 100 & 観血的整復, screw 2 本内固定 \\
\hline
\end{tabular}



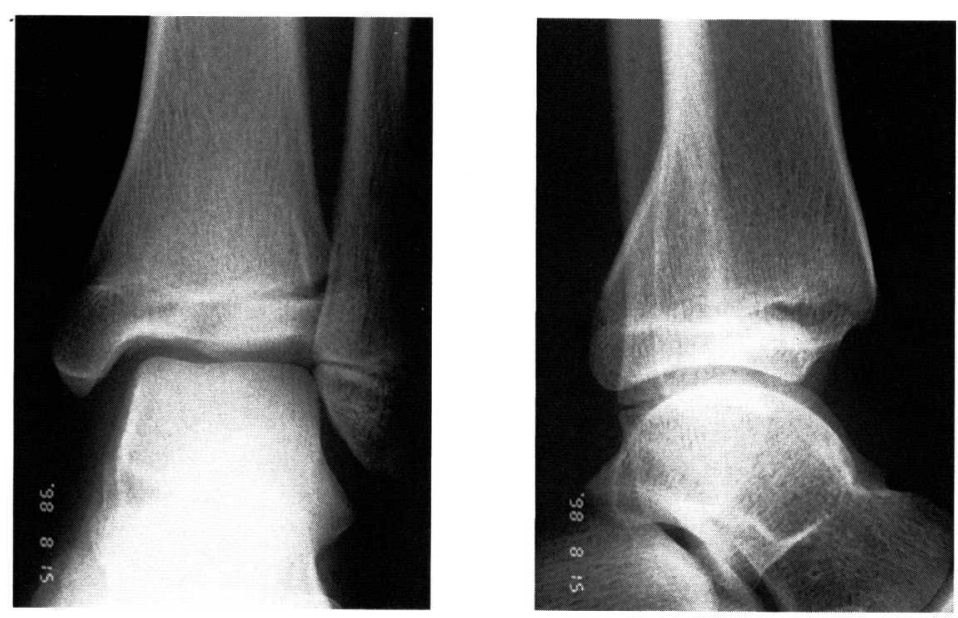

図1 a
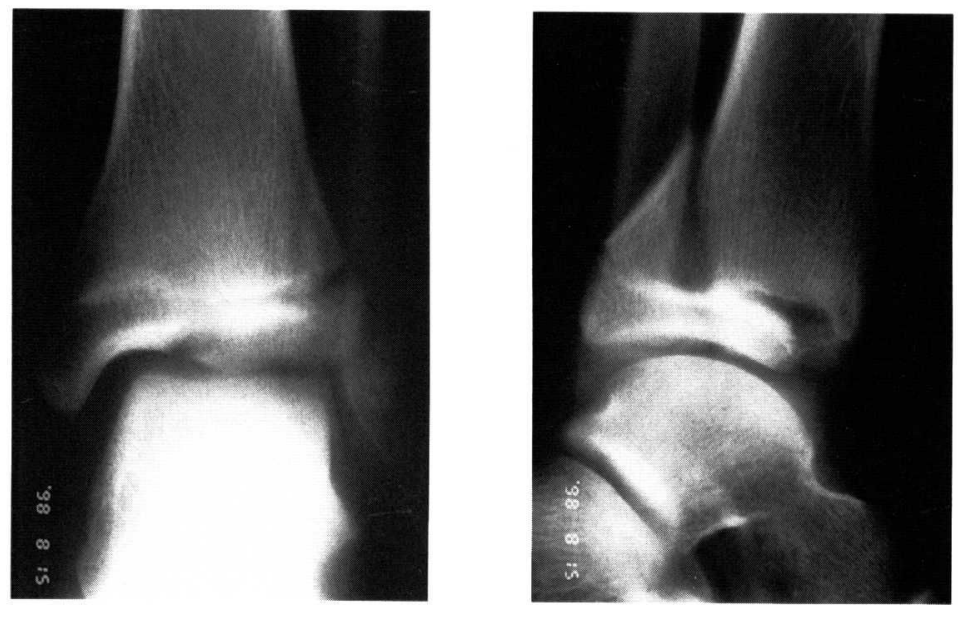

図 1 b
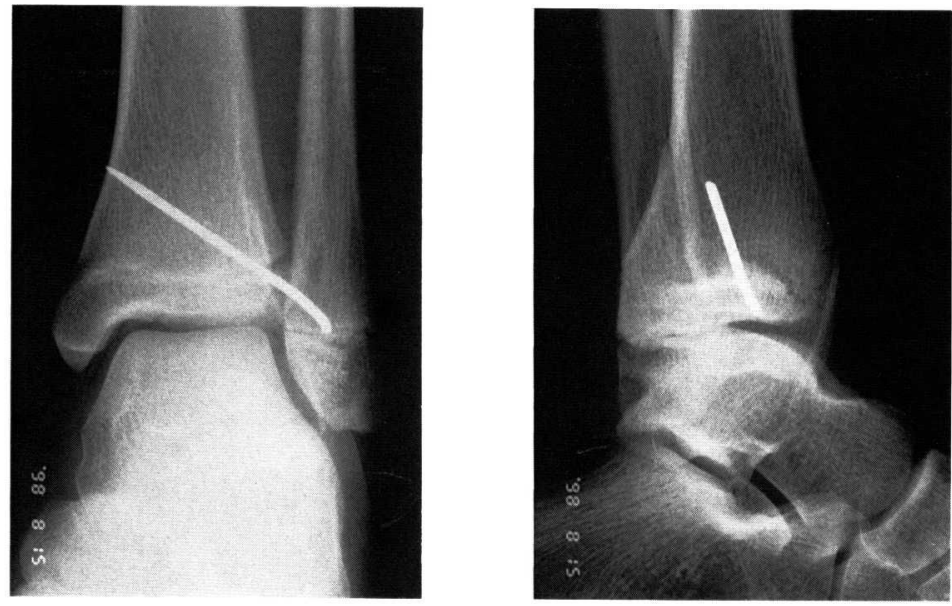

図 1 c

$-117-$ 

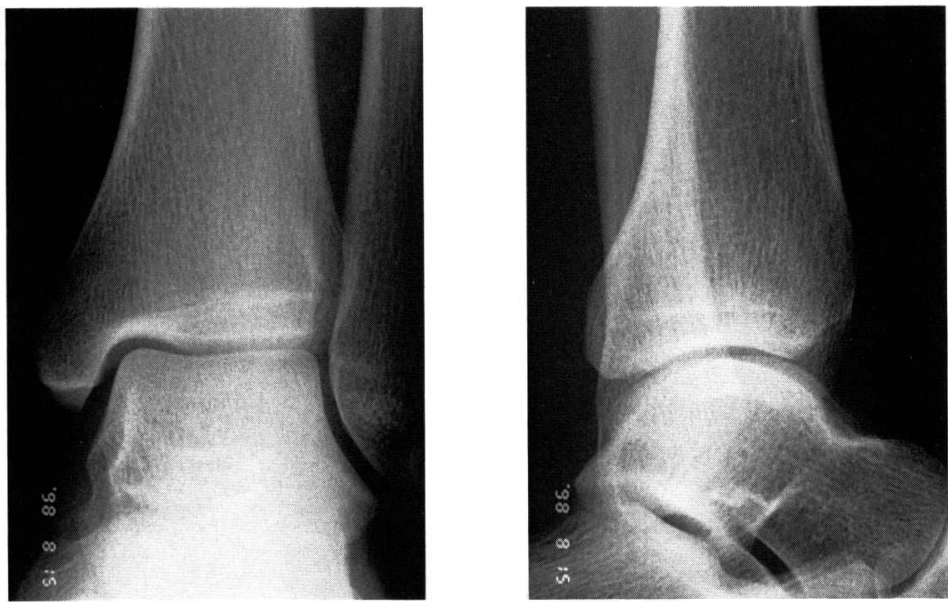

図 $1 d$

図 1 症例 1. 13 歳, 女性.
a. 受傷時単純X線像
b. 断層像における骨端線レベルでの転位は $6 \mathrm{~mm}$.
c. 術後単純 $X$ 線像上転位は $1 \mathrm{~mm}$ 以下.
d。追跡調查時単純 X 線像

\section{症例 2：11 歳, 女性}

ローラーブレードで遊んでいて転倒し，右足関節外 旋一底屈強制を受けて受傷した。レントゲン前後像で Salter-Harris III型，側面像でI型を呈し，Triplene 骨折と診断した．断層像から骨端線レベルでの転位は 約 $7 \mathrm{~mm}$ であり, CT 像で骨折が 4 part であることが
判明した，腰椎麻醉下に徒手整復を試みたが，なかな か良好な整復位を獲得できなかった。整復阻害因子と して中枢骨片之末梢転位骨片間での骨折断端同士の陥 頓が示唆された. 更にイメージ下に内一外旋させると 健常部分の骨端線部分に動摇性を認めた．このため無 理な整復操作を避けるべく転位骨片に $2 \mathrm{~mm} \mathrm{~K}$-wire
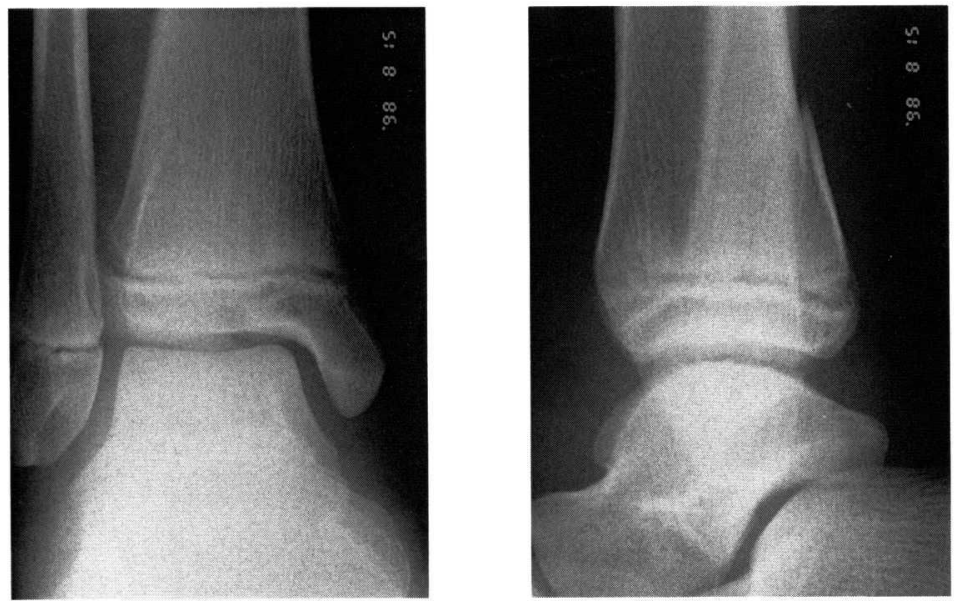

図 2 a 

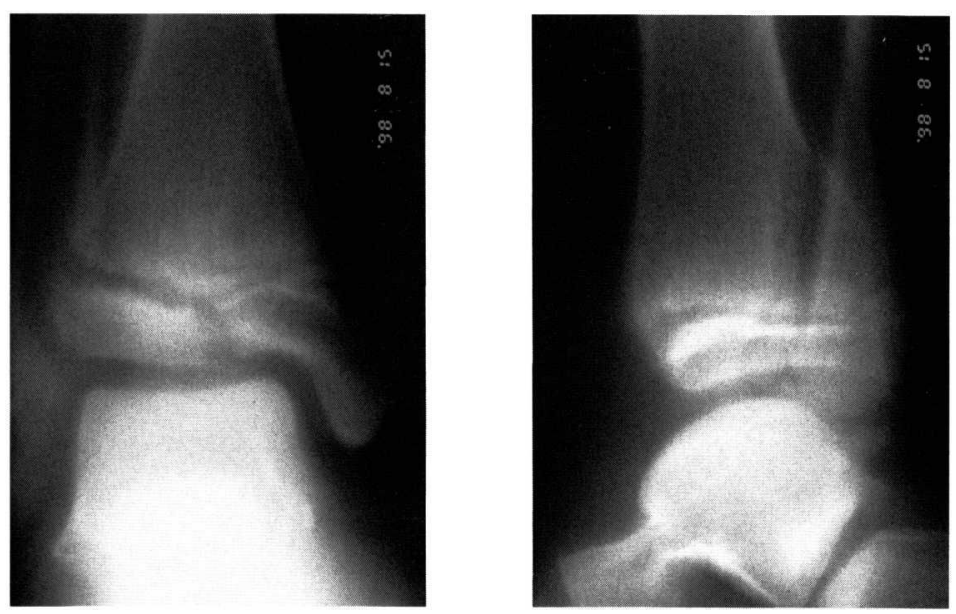

図2 b

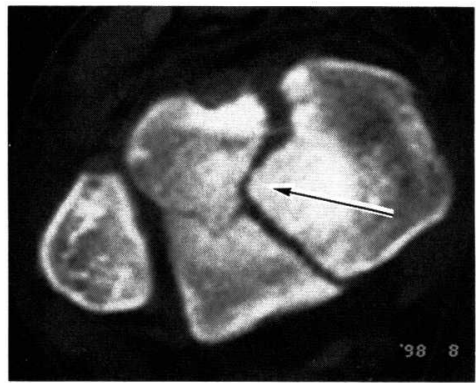

四2 c
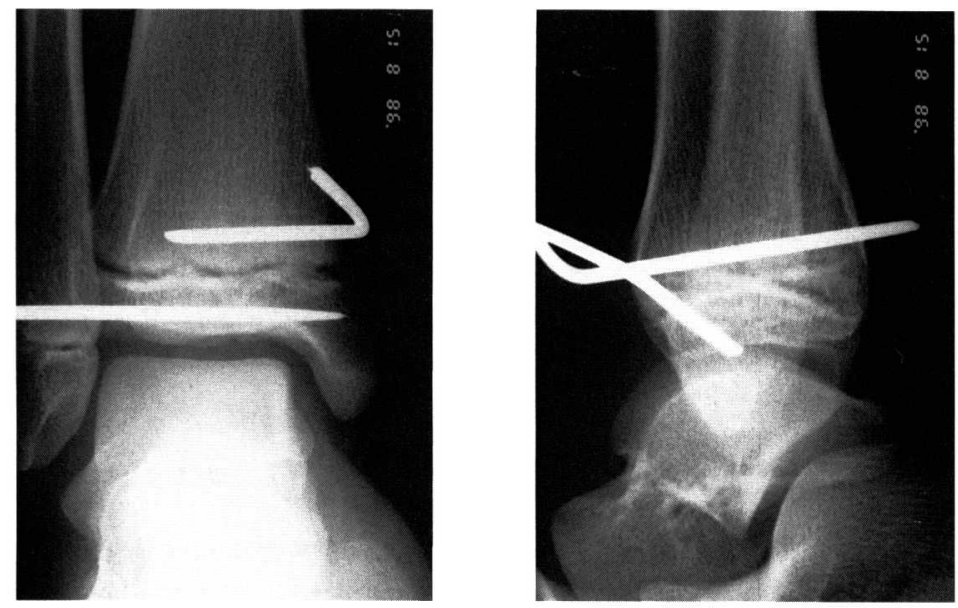

図 $2 d$ 

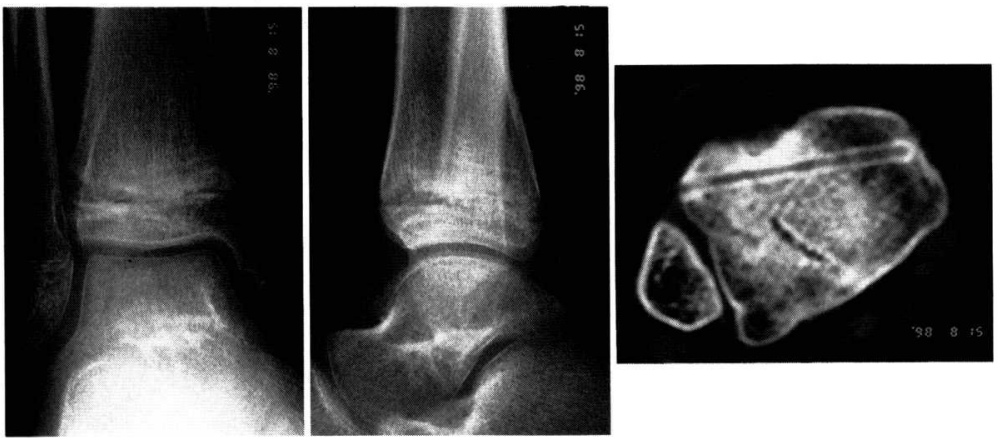

図 2 e

図 2 症例 2, 11 歳, 女性.

a. 受傷時単純 X線像

b. 断層像に抢ける骨端線レベルでの転位は $7 \mathrm{~mm}$.

c. CT 像で, 骨片間の断端が接触し, 整復阻害因子となっている (矢印).

d. 術後単純 X 線像上転位は $1 \mathrm{~mm}$ 以下.

e. 追跡調査時単純 X 線像
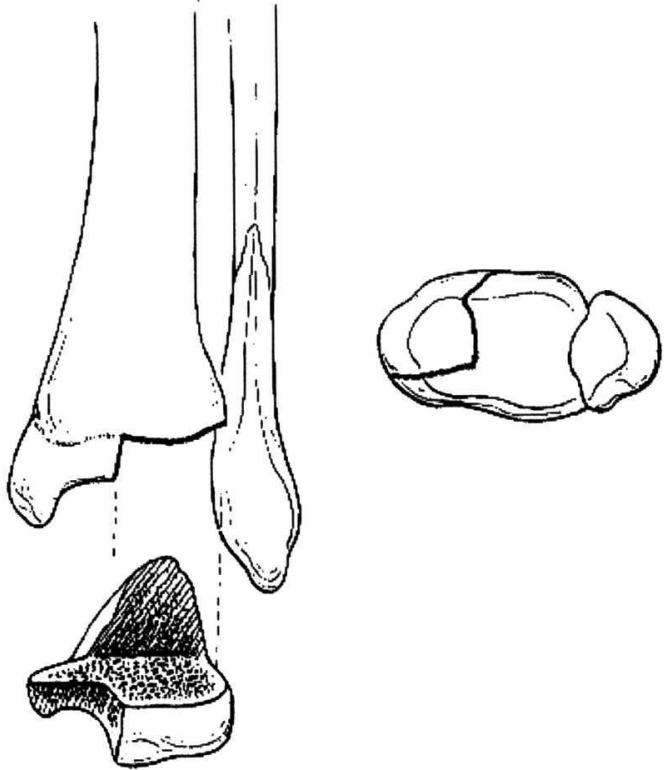

図 3 Triplane 骨折．矢状面，前額面，水平面の三葉骨折 面を有する。

を刺入し，これをテコとして骨片を内旋させると容易 に整復した，そしてその K-wire をそのまま中枢骨片 の内果まで刺入し, 内果の前方から後果を含む骨片に もう 1 本刺入して内固定を行った。術後 6 週間で抜線

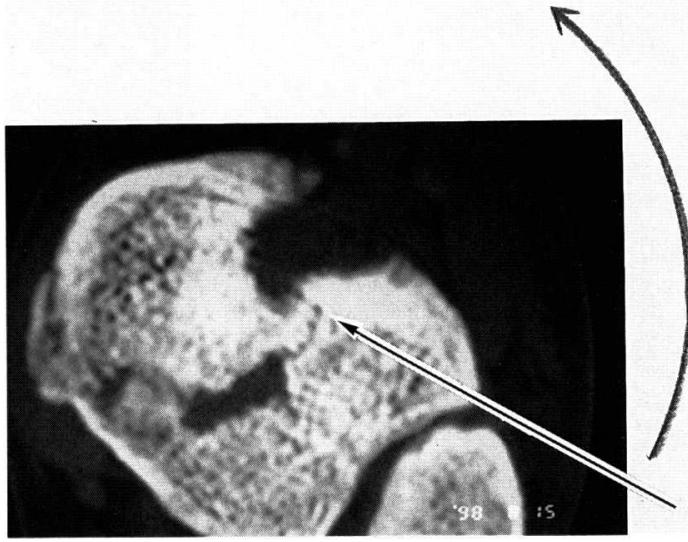

図 4 整復操作．転位した外側末梢骨片に K - wire を外果 前縁より刺入し，内旋力を加える．整復後はこれを 内果まで挿入し，内固定する。

し部分荷重を開始した。受傷後 7 ヶ月の現在，軽度の ROM 制限を認めるものの，日常生活上支障ない（図 $2)$.

考

察

Triplane 骨折は 1970 年, Marmor ら ${ }^{5)}$ が “an unusual fracture of the tibial epiphysis” として最 初に報告し，1972 年，Lynn ら ${ }^{4)}$ によって “the triplane distal tibial epiphyseal fracture” 之命名 
され三次元の骨折型を呈する疾患として認知されるよ うになった（図 3 ). 本症は骨端線が閉鎖する限られ た時期に発生するため Juvenile Tillaux 骨折ととも に “Trasitional fracture” とも呼ばれ，それ故に解 剖学的整復位が得られれば観血的治療による成長障害 などは起こしにくく，概ね成績は良好とされている ${ }^{8)}$. 自検例でも追跡調查時の JOA score は平均 98.2 点之 良好であり，脚長差を呈した例は認めなかった。 すな わち本骨折において重要なことは他の関節内骨折と同 様, 正確な整復位を獲得することである.

整復操作は受傷機転と反対の肢位を強制するため, 受傷機転の理解が必要となる。諸家の報告では(1)3)?) 本骨折の受傷機転として一様に“外旋”で一致してい る. 自検例でも不明を除く 9 例全例が何らかの形で外 旋強制を受けており，イメージ下に外旋強制で骨折部 の転位の増強を認めたことからも主要な受傷機転と考 えられるが，9例中 8 例に底屈強制あ受けていること より底屈力も本症の発生に関与していると考える.

以上より整復操作において，転位末梢骨片に内旋力 を加えることが必要である．実際には足関節を内旋さ せて行うが，中には上記症例提示したような整復困難 な例が存在する．整復阻害因子としてこれまで腓骨骨 折や骨膜陥入 ${ }^{8) 9)}$ などが報告されているが，今回の検 討では関節部の軟部組織や，残存する骨端線による整 復力の緩衝で力が骨折部まで伝わりにくいこと，末梢 転位骨片之中枢骨片の断端同士の接触，陥頓が考えら れた（図4).しかし骨端線が完全に閉鎖していない 例では過度の整復力を加えると新たに健常な骨端線を 損傷しかねない゙).

我々はこうした徒手整復困難例に対し症例 2 のよう に外側転位骨片に K-wire を刺入し，これを利用し内 㙆させることで良好な整復位を獲得することができた。 この方法は経皮的に行うことができ，そのまま内固定 できる．また直接転位骨片だけに内旋力を加えること ができ，健常な骨端線を整復操作によって新たに損傷
することを避けることが可能である．この時注意する ことは, CT で骨折型, 及び転位の方向や程度を把握 しておくこと, 転位骨片の外果前縁より関節面と平行 に刺入すること，整復した状態を想像し，整復後その K-wire が中枢骨片をしっかりと据えられるように予 め角度を付けて挿入することである.

\section{ま と め}

1. 過去 15 年間に当科で治療した Triplane 骨折 13 例， 13 足を追跡調查し，受傷機転と整復操作につ いて検討した.

2. JOA score は平均 98.2 点と良好であった.

3. 本症は足関節外旋一底屈強制で発生すると推察 した.

4. 徒手整復困難例に対し，外側転位骨片に経皮的 に K-wire を刺入し，これを利用して整復する方法が 効果的であった。

\section{参 考 文 献}

1）東 永廉：脛骨遠位骨端線離開の 5 例. 整形外科 41 : 1699-1703, 1990.

2）東田紀彦：骨端線（軟骨板）損傷．整形外科 38 : 1607-1613, 1987.

3）黒羽根洋司 : 脛骨遠位骨端線離開の 7 例. 整形・災害 外科 $30: 223-227,1987$.

4) Lynn, M. D. : The triplane distal tibial epiphyseal fracture. Clin. Orthop., 86 : 187-190, 1972.

5) Marmor, L. : An unusual fracture of the tibial epiphysis. Clin. Orthop., 73 : 132-135, 1970.

6) 門司順一：变形性足関節症と足関節形態の X 線学的計 測. 日整会誌, $54: 791-802,1980$.

7）野村栄貴：若年者にみられる脛骨下端骨端線離開．整 形外科 $39: 175-183,1988$.

8）芝 昌彦:脛骨遠位部 triplane fracture の治療経験. 臨床整形外科 $26: 785-789,1988$.

9）田平礼一：小児における脛骨遠位部 triplane fracture 4 例の治療経験. 整形外科と災害外科 $36: 1136-1138$, 1988. 